\title{
POTRET EPISTEMOLOGI TAFSIR ERA FORMATIF (Peta Kajian Tafsir Klasik Perspektif Filsafat Ilmu)
}

\author{
Fathurrosyid \\ INSTIKA Guluk-Guluk Sumenep Madura \\ Email: fathurrosyid09038@gmail.com
}

\begin{abstract}
Abstrak:
Tulisan ini hendak mengungkap dan meyingkap epistemologi tafsir era formatif dengan mengkonstruksikan pada dua hal; Pertama, bagaimana epistemologi tafsir era klasik. Kedua, bagaimana dialektika tafsir era klasik dengan realitas yang dihadapinya. Kajian ini menghasilkan kesimpulan bahwa tafsir era formatif atau klasik yaitu tafsir yang muncul dan berkembang pada masa Rasulullah hingga munculnya tafsir masa pembukuan (akhir masa Daulah Bani Ummayyah atau awal Daulah Bani Abbasiyyah), yakni abad I H sampai pada abad II H. Adapun salah-satu model berpikir tafsir era formatif yaitu model nalar quasi-kritis yang ditandai dengan; Pertama, penggunaan simbol-simbol tokoh untuk mengatasi persoalan. Kedua, cenderung kurang kritis dalam menerima produk penafsiran; menghindari hal yang konkritrealistis dan berpegang pada hal-hal yang abstrak-metafisis. Dalam konteks peran dan posisi akal, tafsir era formatif menjadikan peran akal hanya sebagai instrumen yang bersifat partisipatif, sedangkan peran periwayatan diberikan porsi sebagai alat jastifikasi.
\end{abstract}

Kata Kunci: Epistemologi, Tafsir Era Formatif dan Filsafat Ilmu

Abstract:

This paper is about to uncover epistemology interpretation formative era by constructing interpretations on two things; First, how epistemology interpretation of classical era. Secondly, how the dialectic interpretation of classical era with the reality that it faces. This study led to the conclusion that the formative era or classic interpretation is the interpretation that emerged and developed at the time of the Prophet until the advent interpretation accounting period (the end of the Daulah Bani Ummayyah or early Daulat Abbasids), the first centuries hijriyah until the second century hijriyah. One of the models think interpretation formative era of quasi-critical reasoning characterized by; First, the use of symbols leaders to address the issues. Secondly, tend to be less critical in 
Potret epistemologi tafsir era formatif (peta kajian tafsir klasik perspektif filsafat ilmu)

receiving product interpretation; avoid concrete-realistic and stick to the things that are abstract-metaphysical. In the context of the role and position sense, formative era interpretation makes sense only as an instrument role that is participatory, while the role of serving as a means of transmission given justification.

Keywords: Epistemologic, Tafsir of Era Formatif and Filsafat since

\section{Prolog}

Menurut pengakuan al-Qur'an sendiri, kehadirannya ke dunia ini, salah-satunya untuk memproklamsikan dirinya sebagai guidance atau sebagai hudan li al-Muttaqīn dan hudan li al-Nās. ${ }^{1}$ Tentu saja, nada proklamasi semacam ini meniscayakan adanya suatu upaya serius bagi para pembacanya untuk melakukan interpretasi dengan cara mengungkap dan menyingkap segala "simpanan kekayaan" al-Quran yang terkandung di dalamnya. Aktivitas tersebut -yang dalam terminologi ulüm al-Qur'andisebut "penafsiran".

Hanya saja, yang menjadi problematik adalah bagaimana memperlakukan "teks" al-Qur'an agar mencapai pada titik subtilitas intelligendi (ketepatan pemahaman) dan subtilitas explicandi (ketepatan penjelasan) mengingat entitas teks itu sendiri sangat potensial terjadinya otoritarianisme penafsiran. Dalam konteks yang demikian, tentu saja agar tidak terjadi interpretive despotism, ${ }^{3}$ maka kerja keras untuk mengungkap

\footnotetext{
${ }^{1}$ Dalam konteks semacam ini, al-Qur'an seringkali di berbagai tempat atau surat memproklamasikan dirinya sebagai "hudan li al-Nās", sebut saja misalnya, di awal permulaan surat al-Baqarah, al-Qur'an dengan tegas menyatakan sebagai "hudan li al-Muttaqīn". Lihat al-Qur'an, 2 (al-Baqarah: 2).

${ }^{2}$ Secara etimologis, tafsir adalah penjelasan atau keterangan (al-Ị̣ah, al-Bayān wa al-Tabyīn). Ibnu Manzūr al-Afrììi, Lisān al-'Arab, Jilid V (Beirut: Dār al-Sadr, 1992), 55; dan Louis Ma'luf, Al-Munjid fí al-Lugah wa al-A'lam (Beirut: Maktabah al-Shāriqah, 1996), 583. Selain itu, tafsir juga dapat berarti al-Kashf wa al-Izhär, penyingkapan atau penampakan makna. Lihat al-Jurjāni, Kitab al-Ta'rifät (Beirut: Dār al-Kutub al-'Ilmiyyah, 1998), 63. Sedangkan secara terminologis, tafsir adalah upaya menyingkap atau menjelaskan suatu masalah pelik (musykil) sesuai dengan yang dimaksudkan. Lihat; Muhammad Farid Wajdi, Dairah Ma'arif al-Qarn al-'Isyrin, Jilid VII (Beirut: Dār al-Fikr, t.t.), 286. Terminologi demikian, jika dihubungkan dengan ilmu penafsiran al-Qur'an, maka tafsir adalah berarti ilmu yang berupaya memahami al-Qur'an yang diturunkan kepada Nabi Muhammad SAW dengan menjelaskan makna-maknanya yang tersirat serta mengeluarkan hukum-hukum dan mutiaramutiara hikmah yang dikandungnya. Lihat selengkapnya; Muhammad Ibn 'Abdullah alZarkashī, Al-Burhān fí 'Ulūm al-Qur'ān, Juz I (Beirut: Dār al-Ma'arifah,1972), 13.

${ }^{3}$ Istilah interpretive despotism (penafsiran sewenang-sewenang) dipopulerkan oleh Khaled M. Abou el-Fadl. Baginya, otoritarianisme merupakan tindakan mengunci kehendak Tuhan atau kehendak teks dalam sebuah penetapan tertentu dan kemudian menyajikan penetapan tersebut sebagai seustau yang given. Ini semua terjadi akibat dari sebuah kesalahan
} 
Potret epistemologi tafsir era formatif (peta kajian tafsir klasik perspektif filsafat ilmu)

dan menangkap weltanschauung al-Qur'an dengan menggunakan pisau iris ilmu-ilmu linguistik ('Ulüm al-Lughah) merupakan solusi yang kredibel dan visibel.

Berangkat dari fenomena di atas, tulisan ini hendak mengungkap dan meyingkap dua hal; Pertama, bagaimana epistemologi tafsir era klasik. Kedua, bagaimana dialektika tafsir era klasik dengan realitas yang dihadapinya. Adapun tujuan yang hendak dicapai dari penelitian ini adalah untuk memberikan penjelasan bagaimana tafsir era klasik ini dikonstruksi dan dialektikan dengan realitas yang dihadapi oleh mufassirnya. Namun demikian, penulis perlu memberikan batasan tentang tafsir era klasik atau era formatif dalam penelitian ini. Adapun yang dimaksud dengan tafsir era klasik, penulis merujuk pada kategorisasi yang digagas oleh Husain alDhahabi yaitu tafsir yang muncul dan berkembang pada masa Rasulullah hingga munculnya tafsir masa pembukuan (akhir masa Daulah Bani Ummayyah atau awal Daulah Bani Abbasiyyah), yakni abad I H sampai pada abad II H. ${ }^{4}$ Hanya saja, untuk memudahkan penulis dalam kajian ini, penulis hanya fokus pada abad I H saja.

\section{Dialektika Tafsir Era Formatif dengan Realitas}

Tafsir era formatif merupakan sebuah model atau cara berpikir yang kurang memaksimalkan atau memberikan porsi lebih pada penggunaan rasio dalam menafsirkan al-Qur'an dan juga belum mengemukakannya budaya kritisisme. ${ }^{5}$ Artinya, dalam konteks peran dan posisi akal, tafsir era formatif menjadikan peran akal hanya sebagai instrumen yang bersifat partisipatif, sedangkan peran periwayatan diberikan porsi sebagai alat justifikatif. Kondisi yang demikian tentu sangat berbeda dengan model dan cara kerja tafsir pada era berikutnya, yaitu era pertengahan. Pada era tersebut, posisi akal sebagai instrumen yang bersifat jastifikatif, sedangkan posisi periwayatan diberikan peran sebagai alat partisipatif. Dengan demikian, era tafsir formatif merupakan model berpikir nalar-quasi kritis.

Adapun salah-satu model berpikir nalar quasi-kritis antara lain ditandai dengan; Pertama, penggunaan simbol-simbol tokoh untuk mengatasi persoalan. Dalam konteks penafsiran, simbol tokoh seperti nabi, para sahabat dan bahkan para tabi'in cenderung dijadikan sebagai rujukan

prosedural metodologis terkait relasi antara ketiga unsur, yaitu; teks, author dan reader. Lihat selengkapnya, Khaled M. Abou el-Fadhl, Atas Nama Tuhan; Dari Fiqih Otoriter ke Fiqih Otoritatif, terj. Cecep Lukman Yasin (Jakarta: Serambi, 2004), 212.

${ }^{4}$ Muhammad Husain al-Dhahabī, al-Tafsìr wa al-Mufassirūn, Vol. I (Beirut: Dar al-Fikr, 1396), 25.

${ }^{5}$ Abdullah Mustaqim, Epistemologi Tafsir Kontemporer(Yogyakarta: LKiS, 2010), 34. 
Potret epistemologi tafsir era formatif (peta kajian tafsir klasik perspektif filsafat ilmu)

utama dalam penafsiran al-Qur'an. Standar kebenaran tafsir juga ditentukan oleh ketokohan orang-orang tersebut. Kedua, cenderung kurang kritis dalam menerima produk penafsiran; menghindari hal yang konkrit-realistis dan berpegang pada hal-hal yang abstrak-metafisis. Dalam konteks penafsiran, al-Qur'an cenderung diposisikan sebagai subjek, sedangkan realitas dan penafsirannya diposisikan sebagai objek. Dengan kata lain, posisi teks menjadi sangat sentral sehingga model berpikir deduktif lebih mengemuka dari pada model berpikir induktif. Oleh karena itu, tidak mengherankan jika pada era formatif ini yang dominan adalah model tafsir bi al-riwayah, sedangkan tafsir bi al-ra'yi cenderung dihindari dan bahkan dicurigai. ${ }^{6}$

\section{Potret Tafsir Nabi Muhammad saw; Sang Mufassir Otoritatif}

Begitu al-Qur'an diturunkan, maka Rasulullah adalah sosok yang paling "bertanggung jawab" untuk menyampaikan pesan-pesan suci pada umatnya. Karena itu, sebagai pembawa risalah, Rasulullah diberi otoritas penuh oleh Tuhan untuk menjelaskan pesan wahyu kepada umatnya ketika mereka mendapatkan kesulitan dalam memahami teks wahyu. ${ }^{7}$ Tuhan juga memerintah agar semua yang disampaikan oleh Rasul -dalam konteks risalah- harus diterima (taken for grented) tanpa reserve. ${ }^{8}$

Berangkat dari basis data di atas, maka aktivitas penafsiran sudah dimulai semenjak Rasulullah menyampaikan risalah Tuhan yang datang dalam bentuk al-Qur'an. Artinya, tugas penafsiran menjadi bagian integral dari tugas risalah yang diemban beliau. Oleh karena itulah maka Tuhan sendiri menjamin bahwa Rasulullah dapat mengikuti bacaan al-Qur'ân, menghimpun dan menjelaskannya, ${ }^{9}$ sehingga tidak diragukan lagi bahwa beliau merupakan sosok mulia yang secara otoritatif lebih paham dengan kehendak Tuhan dan beliau menjadi satu-satunya sumber rujukan otentik dalam memahami ayat-ayat al-Qur'ān.

Hanya saja, bentuk kegiatan penafsiran yang dilakukan Rasulullah waktu itu masih simplistis karena disampaikan dengan pola ijmāli dan ditransimisikan secara oral, mengingat peradaban Arab waktu itu masih merupakan peradaban lisan dan periwayatan. Terkait dengan keterlibatan Rasulullah dalam menafsirkan al-Qur' an, Ibnu Khaldūn dalam Muqaddimahnya pernah mengatakan:

"Rasulullah menjelaskan makna al-Qur'ân secara umum, membedakan ayat-ayat yang nāsikh dan mansūkh, kemudian memberitahukan

\footnotetext{
${ }^{6}$ Ibid.,

${ }^{7}$ Qs. al-Nahl: 44 dan 64.

${ }^{8}$ Qs. al-Hasr: 7.

${ }^{9}$ Qs. al-Qiyâmah: 17-19.
} 
kepada para sahabat, sehingga mereka memahami sebab musabab turunnya ayat (asbāb al-nuzū $l$ ) dan situasi yang mendukungnya". ${ }^{10}$

Deskripsi singkat Ibnu Khaldūn di atas, dapat dijadikan kompas penunjuk tentang keterlibatan Rasulullah secara intensif dalam dunia penafsiran. Sekalipun demikian, betapa pun Rasulullah sangat aktif terlibat dalam penafsiran al-Qur'an, namun tidak semua ayat al-Qur'an ditafsirkan beliau. ${ }^{11}$ Penafsiran terhadap ayat al-Qur'an sering kali dilakukan Rasulullah dalam rangka hanya menjelaskan ayat yang dianggap sulit saja oleh sebagian sahabat. Jarangnya Nabi saw. melakukan penafsiran terhadap ayat-ayat alQur'an lebih dikarenakan sasaran wahyu pada waktu itu adalah orang-orang Arab asli yang menguasai bahasa Arab dan memiliki cita rasa bahasa (Dhauq al-Lughah al-Salim) yang cukup baik, sehingga mereka dapat memahami alQur'an dengan baik dan mengetahui aspek-aspek balaghah yang ada di dalamnya, mengingat al-Qur'an diturunkan dengan menggunakan bahasa mereka, ${ }^{12}$ seperti kata zulm (aniaya) ${ }^{13}$ yang ditafsirkan oleh Rasulullah dengan shirk yang terdapat pada QS. Luqmān: $13 .{ }^{14}$

Disamping itu pula, sistem penafsiran yang digunakan oleh Rasulullah dalam rangka menjelaskan firman Allah adalah dengan menggunakan sumber informasi dari al-Qur'an itu sendiri, istinbät, ishäri, mengkhususkan ayat-ayat yang mempunyai kandungan makna umum (takhṣiṣ al-'ām), mengumumkan yang khusus (ta'mìm al-khās), pendekatan bahasa (al-tafsir

\footnotetext{
${ }^{10}$ Ibnu Khaldūn, Muqaddimah Ibnu Khaldūn (Bairut: Dār al-Fikr: t.th), 489.

${ }^{11}$ Terkait tentang penafsiran Rasulullah, terjadi kontroversi di antara para ulama yang dapat diklasifikasikan menjadi dua kubu. Pertama, kubu yang digagas oleh Ibnu Taimiyah. Kubu ini, dengan berbagai argumentasi baik melalui naql maupun 'aql, menyatakan bahwa Rasulullah telah menafsirkan semua isi al-Qur'an, baik secara global maupun spesifik. Kedua, kubu yang diusung oleh Imam al-Suyūṭ̂i dan Shamsuddin al-Khāwì. Dalam catatan kelompok ini yang juga disertai dengan berbagai argumentasi, menolak keras bahwa Rasulullah hanya menafsirkan sebagian kecil dari semua ayat al-Qur'an. Dari perseteruan dua kubu ini, Muhammad Husain al-Dhahabī mencoba menjadi fasilitator dengan cara mengkompromikan argumentasi keduanya. Menurutnya, bahwa Rasulullah telah menjelaskan semua makna al-Qur'an dan juga tidak menjelaskan semua maknanya. Ini dikarenakan secara faktual -dengan mengutip pendapat Ibnu Abbās-, bahwa (a) Di dalam al-Qur'an terdapat bagian-bagian yang hanya diketahui maksudnya oleh Allah semata (tafsir la ya'lamuhū illa Allah), (b) terdapat bagian yang dapat diketahui oleh para ulama (tafsir ta'rifuhā al- 'Ulama'), (c) terdapat bagian yang dapat diketahui oleh orang-orang yang menguasai bahasa Arab (wajhun ta'rifuhū al-'Arab min Kalamihä), (d) terdapat bagian yang dengan mudah dapat diketahui oleh orang bodoh sekalipun (tafsir la ya'taziru ahadun bi juhālatihî). Lihat selengkapnya; Muhammad Husain al-Dhahabì, al-Tafsir wa al-Mufassirün,....., 53.

${ }^{12}$ Qs. Yūsuf: 2 dan Qs. al-Zukhrūf: 3.

${ }^{13}$ Qs. al-An'ām: 82.

${ }^{14}$ Lihat al-Zarqānī, Manāhil al-'Irfān, Vol. 2 (Beirut: Dār al-Kutb al-'Ilmiyyah, t.th.), 271.
} 
Potret epistemologi tafsir era formatif (peta kajian tafsir klasik perspektif filsafat ilmu)

al-lughawi) dan lainnya, ${ }^{15}$ sehingga bukan menjadi hal yang aneh jika pasca wafatnya Rasulullah, variasi pendapat seputar tafsir ayat-ayat al-Qur'an di kalangan para sahabat, merupakan indikasi konkrit ke arah keterlibatan penafsiran Rasulullah yang dilakukan secara tidak maksimal dan totalitas, sebagaimana akan diuraikan berikutnya.

\section{Epistemologi Tafsir Era Sahabat; Model Nalar Quasi-Kritis}

Pada umumnya, para sahabat dapat menafsirkan al-Qur'an, sebab mereka adalah orang-orang yang langsung mendapatkan pendidikan dari sumber paling otoritatif dalam menginterpretasi al-Qur'an (baca: Nabi Muhammad saw.), yang selalu berusaha memahami, mengerti, memikirkan, merenungi wahyu Ilahi untuk mengeluarkan mutiara hikmah yang terkandung di dalamnya, ${ }^{16}$ sehingga al-Qur'an benar-benar menjadi kitab petunjuk (guidance) bagi mereka. Mereka juga merupakan pelaku sekaligus saksi sejarah ketika wahyu Ilahi diturunkan. ${ }^{17}$ Faktor-faktor inilah yang kemudian menjadikan mereka sebagai orang yang faham dan mengerti tentang kehendak Tuhan dalam firman-firmannya. Di samping karena memang al-Qur'ān diturunkan dengan menggunakan bahasa mereka sendiri.

Sekalipun demikian, Ibnu Qutaibah menyatakan bahwa orang-orang Arab (termasuk para sahabat) tidak sama dalam memahami segala sesuatu yang gharīb dan mutashābih di dalam al-Qur'ān. Masing-masing dari mereka mempunyai tingkat pemahaman yang berbeda-beda. Perbedaan ini lebih dikarenakan perbedaan tingkat intensitas mereka dalam menggali informasi keagamaan dari Rasulullah, kapasitas intetektual yang mereka miliki, serta penguasaan mereka terhadap perbendaharaan khazanah intelektual yang berkembang pada waktu itu, ${ }^{18}$ shingga jawara tafsir yang paling menonjol diantara mereka adalah sepuluh orang yaitu: khalifah yang empat, Ibnū

\footnotetext{
${ }^{15}$ Lebih jelasnya lihat; 'Abd al-Ghafūr Maḥmūd Muștafā Ja'far, al-Tafsīir wa al-Mufassinūn fi Thaubihi al-Jadìd (Kairo: Dār al-Salām, 2007), 446.

${ }^{16}$ Lihat Muștafá Ja'far, al-Tafsìr wa al-Mufassinūn,..... 446-447.

${ }^{17}$ Mannā' al-Qaț̣ān, Mabāhith fi 'Uh̄̄m al-Qur'ān, (t.tp: Manshurāt al-'Aṣr al-Ḥadith, 1973), 337.

${ }^{18}$ Lihat Mușțafa Ja'far, al-Tafsìr wa al-Mufassin̄̄n,..... 447-448. Muhammad Baqir Hâkim juga menyatakan bahwa diturunkannya al-Qur'an dengan bahasa Arab dan dengan menggunakan cara-cara pengungkapan yang dapat dipahami bangsa Arab, tidaklah cukup memberi bukti bahwa mereka secara umum dapat memahami al-Qur'an dan mengetahui makna-makna, hukum-hukum dan ajaran-ajaran yang terkandung didalamnya, baik yang berupa lafaz tertentu, kalimat-kalimat tertentu maupun yang terangkai dalam susunan kalimat. Mụhammad Baqir Ḥakim, 'Uhùm al-Qur'ān, ter. Nashirul Haq dkk, (Jakarta: alHuda, 2006), 372.
} 
Potret epistemologi tafsir era formatif

(peta kajian tafsir klasik perspektif filsafat ilmu)

Mas'ūd, Ibn 'Abbās, Ubayy bin Ka'b, Zaid bin Thābit, Abū Mūsa al-Ash'ari dan Abdullah ibn Zubair. ${ }^{19}$

Dari Khalifah empat, yang paling banyak meriwayatkan tafsir adalah 'Ali bin Abi Ṭâlib ${ }^{20}$ dibandingkan dengan tiga khalifah sebelumnya. Hal hal itu karena mereka terlebih dahulu meninggal dunia dari pada 'Ali bin Abì Ṭālib serta kesibukan dan intensitas mereka dengan aktivitas kekhalifahan, ${ }^{21}$ sehingga wajar jika penafsirannya relatif lebih banyak dari yang lain. Selain 'Ali bin Abi Țālib, ada lagi kalangan sahabat yang banyak meriwayatkan tafsir yaitu Ibn Mas'ūd dan riwayatnya jauh lebih banyak dari pada riwayat 'Ali bin Abi Tâalib. ${ }^{22}$ Namun meski demikian, dari sekian banyak sahabat yang menafsirkan al-Qur'ān, Ibn 'Abbās dipandang sebagai tokoh yang paling terkemuka dari pada yang lain, sehingga beliau diberi gelar penerjemah al-Qur'ân ( Tarjumān al-Qur'ān) dan dianggap sebagai peletak dasar disiplin ilmu tafsir. ${ }^{23}$

Namun sangat disayangkan, legitimasi dan justifikasi keilmuan yang diberikan Rasulullah kepada Ibn 'Abbās selanjutnya banyak dimanfaatkan oleh orang yang ditunggangi interes pribadi, sehingga ucapannya banyak yang ditambah dan diselewengkan, bahkan sebagian orang meriwayatkan beberapa kebohongan yang kemudian dinisbatkan pada Ibnū 'Abbās. ${ }^{24}$

\footnotetext{
${ }^{19}$ Mannā' al-Qațtan, Mabāhth fi 'Ulūm al-Qur'ā̄,..... 343.

${ }^{20}$ Menurut Muștafā Ja'far, lebih dari seratus lima puluh penafsiran 'Ali bin Abī Țālib yang dijadikan referensi oleh al-Qurțubiy dalam karya tafsirnya. Mușțafā Ja'far, al-Tafsìr wa alMufassinūn,..... 460.

${ }^{21}$ Ibid. Lihat juga al-Qațtan, Mabāḥith, 343. Bandingkan dengan; Muhammad Husain alDhahabì, al-Tafsir wa al-Mufassirūn,....Vol. I, 64.

${ }^{22}$ Ibnu Jarìr, Masrūq dan yang lainnya meriwayatkan perkataan Ibn Mas'ūd: "Demi zat yang tidak ada Tuhan selain-Nya, tidak ada satu ayat pun dari al-Qur'an yang diturunkan kecuali aku mengetahui kepada siapa ayat itu diturunkan dan di mana diturunkan, jika aku mengetahui ada seseorang yang lebih tahu dariku maka aku akan mendatanginya". Lihat selengkapnya; Mustafā Dib al-Bigā, al-Wādih fi 'Ulūm al-Qur'ān (Damaskud: Dār al-'Ulūm al-Insāniyah, 1418), 224.

${ }^{23}$ Ada beberapa faktor mengapa Ibn 'Abbās menonjol di bidang tafsir di banding sahabatsahabat yang lain, yaitu: Pertama, berkat doa Nabi saw. yang pernah mendoakannya, "allāhumma faqqihhu fí al-Dīn wa 'allimhu al-ta'wil". Kedua, ia dekat dengan 'Umar bin Khațāab, seorang sahabat senior yang begitu besar memberikan perhatian dan motivasi kepadanya agar menekuni disiplin tafsir. Ketiga, intensitas Ibn 'Abbās dalam mengambil ilmu dari tokoh-tokoh sahabat yang lain. Keempat, kekuatan dan ketajaman Ibnū 'Abbās dalam melakukan istinbät dan ijtihäd. Kelima, keseriusan beliau dalam menekuni dan konsen pada bidang tafsir al-Qur'ān. Lihat selengkapnya; Muhammad Husain al-Dhahabi, al-Tafsir wa al-Mufassirūn,.....67-68. Bandingkan dengan; Muhammad 'Abdullāh ibn 'Ali alKhudlairi, Tafsìr al-Täbi'īn, Vol.1 (Riyād: Dār al-Wațan wa al-Nashr, 1999), 374-387. Bandingkan dengan Muhammad 'Ali 'Abd al-Qādir, Faị̣ al-Rahmān fị'Uhūm al-Qur'ān (Kairo: Dâr al-Ṭibā' at al-Muhammadiyah, 1986), 20.

${ }^{24}$ Lebih jelasnya lihat al-Qaț̣àn, Mabähth,..... 360-362.
} 
Potret epistemologi tafsir era formatif (peta kajian tafsir klasik perspektif filsafat ilmu)

Bahkan al-Imâm al-Shâfi'i menyatakan bahwa hampir tidak ada penjelasan Ibnū 'Abbās tentang tafsir yang asli kecuali seratus hadis. ${ }^{25}$

Selain tokoh-tokoh tafsir yang telah disebutkan di atas, di kalangan sahabat masih ada lagi mufassir yang lain. Hanya saja, riwayat mereka ini tergolong sangat sedikit bila dibandingkan dengan sepuluh mufassir yang disebutkan tadi. Mereka adalah; Abū Hurairah, Anas bin Mālik, 'Abd Allāh bin 'Umar, Jābir bin 'Abd Allāh, dan 'Aisyah. ${ }^{26}$ Hal ini dikarenakan konsentrasi mereka lebih banyak tercurahkan pada bidang hadis daripada tafsir. Dalam perjalanan waktu, generasi sahabat ini berakhir pada tahun 110 Hijriyah dengan meninggalnya Abū al-Ṭufail. ${ }^{27}$

Adapun mengenai tradisi dan sistem penafsiran di era sahabat juga masih bersifat oral dengan menggunakan metode periwayatan (bi alriwāyah). Hasil penafsiran dari Nabi saw itulah yang ditrasmisikan kepada generasi berikutnya. Trend penafsiran dengan al-riwāyah ini ditengarai karena adanya sikap kehati-hatian mereka yang dimungkinkan akan tergelincir pada kesalahan. ${ }^{28}$ Namun, ketika para sahabat tidak menemukan penjelasan dari Nabi saw, maka dengan mudah mereka merujuk pada penggunaan bahasa dan syair-syair Arab, sebagaimana yang dilakukan Sayyidina Umar bin al-Khattab. ${ }^{29}$ Selain itu, penafsiran di era sahabat di

\footnotetext{
${ }^{25}$ Jalāl al-Dìn al-Suyūtì, al-Itqān fi 'Ulūm al-Qur'ān,Vol. 2 (t.tp: Dar al-fikr, t.th), 225.

${ }^{26}$ al-Zarqānī, Manāhil al-'Irfän,...... 273.

${ }^{27}$ Muștafā Ja'far, al-Tafsìr wa al-Mufassinūn,..... 448. Bandingkan dengan Jalāl al-Dīn Abu alFaḍl 'abd al-Raḥmān al-Suyuți, Tadrīb al-Rāwi fi Sharh Taqrīb al-Nawāwi, Vol.2 (t.tp: Dâr al-Fikr, t.th), 228.

${ }^{28}$ Kondisi demikian, seperti digambarkan dalam ucapan Abū Bakar ketika ditanya tentang makna satu huruf dalam al-Qur'an. Dengan lantang beliau berkata, "Di mana bumi tempat aku berpijak dan angit tempat aku berteduh serta kemana aku akan lari jika yang aku ucapkan itu salah, meskipun hanya satu huruf'. Begitu pula sikap 'Umar ibn al-Khattâb ketika Ibn Shābigh bertanya kepadanya tentang ayat-ayat mutashâbih, Umar waktu itu malah marah dan mencambuknya. Lihat selengkapnya; Ignaz Goldziher, Madzhab Tafsir, terj. M. Alaika Salamullah (Yogyakarta: eLSAQ Press, 2006), 73-80.

${ }^{29}$ Misalnya, 'Umar ibn al-Khattāab suatu ketika pernah bertanya tentang arti takhawwuf dalam firman Allah: Auw ya'khuzuhum 'ala takhawwuf(QS. al-Nahl [16]:47). Seorang kakek dari kabilah Huzail menjelaskan bahwa artinya adalah tanaqqus (berangsur-angsur, sedikit demi sedikit), seperti dalam syair, "takhawwafa al-rahl minha tâmikan qardan kamâ takhawwafa 'üdan al-nabi' 'ah al-safinu (sedikit demi sedikit [berangsur-angsur] unta itu menjadi gemuk dan banyak kutunya, sebagaimana halnya angin meniup dahan pohon Nab'ah sedikit demi sedikit). 'Umar lalu mengatakan kepada para sahabatnya: "Berpeganglah kalian pada diwandiwan kalian, niscaya kalian tidak keliru (dalam menafsirkan al-Qur'an), sebab sesungguhnya dalam syair Arab Kuno terdapat penjelasan untuk kitab kalian dan makna-makna dalam percakapan kalian". Lihat selengkapnya; Muhammad Husain al-Dhahabī, Al-Tafsïr wa alMufassinūn,..... 74.
} 
Potret epistemologi tafsir era formatif (peta kajian tafsir klasik perspektif filsafat ilmu)

samping al-Qur'an, hadis, bahasa dan syair-syair Arab adalah variasi bacaan (qirā'ah) al-Qur'ān.

Berdasarkan fakta di atas, untuk sementara ini dapat ditarik tali simpulnya, bahwa sumber penafsiran pada era sahabat meliputi beberapa hal, ${ }^{30}$ yaitu; Pertama, al-Qur'an. Kedua, sunnah nabi. Keempat, lughat atau syair Arab Kuno. Kelima, ahli kitab. Keenam, ijtihad (logika). ${ }^{31}$

Karena itu, pada sub di bawah ini, penulis akan lebih memfokuskan dan menyoroti secara detail tentang aplikasi teori penafsiran mereka, khususnya pada penafsiran Ibnu Abbas dan Abdullah bin Mas'ud dengan alasan, sebagaimana telah dikemukakan di atas.

\section{a. Aplikasi Tafsir Ibnu Abbas}

Ibnu Abbas $^{32}$ adalah sosok yang memiliki predikat sebagai tinta (al-Hibr) dan lautan (al-Bahr) ilmu bagi ummat. Ini dikarenakan kecerdasan dan kehebatannya dalam berijtihad dan memahami rahasia-rahasia terdalam dari al-Qur'an. Selain karena faktor doa "kecerdasan" yang dipanjatkan Rasulullah, ${ }^{33}$ kualifikasi dan kredebilitasnya dalam disiplin ilmu tafsir juga ditopang oleh ketekunan dan keseriusannya dalam disiplin ilmu tersebut. Dari fenomena semacam ini, akhirnya Ibnu Abbas dijadikan literatur dan rujukan utama oleh hampir semua para sahabat dan tabi'in di saat

${ }^{30}$ Musā'id bin Sulaimān al-Tayyār, Fușūl fi Usūl al-Tafsīr (Riyād: Dār al-Nashr al-Dauli, 1413), 35 .

${ }^{31}$ Metode Ijtihad para sahabat berdasarkan pada lima hal; Pertama, penguasaan tema-tema bahasa Arab dan rahasia yang terkandung di dalamnya. Kedua, pengetahuan tentang tradisi masyarakat Arab. Ketiga, pengetahuan tentang kondisi orang-orang Yahudi dan Nasrani di jazirah Arab ketika turunnya wahyu. Keempat, pengetahuan tentang konteks historis turunnya ayat al-Qur'an. Kelima, kekuatan dan keluasan pemahaman atas ayat al-Qur'an. Lihat; Abd al-Qādir Muhammad Șālih, al-Tafsìr wa al-Mufassiruñ fi al-'Asri al-Hadith (Beirut: Dār al-Ma'rifah: 1424), 90.

${ }^{32}$ Nama lengkapnya adalah 'Abdullah bin 'Abbās bin 'Abd al-Muṭallib bin Hasyim bin 'Abdi Manaf al-Qurshì al-Hāshimì. Beliau dilahirkan 3 tahun sebelum Rasulullah hijrah. Ketika Rasulullah wafat, Ibnu Abbas sudah berusia 13 tahun. Beliau menghembuskan nafas terakhirnya di Țaif dan dikuburkan di sana dalam usia 68 tahun. Lihat; Muhammad Husain al-Dhahabi, al-Tafsir wa al-Mufassirun, ..... 65.

${ }^{33}$ Diceritakan dari Sa'īd bin Jubair dari Ibnu 'Abbās, bahwa Ketika Rasulullah berada di rumah Maimunah, Ibnu Abbas juga ikut bermalam di sana, karena Maimunah adalah bibinya sendiri. Pada saat Rasulullah bangun dari tidurnya, maka Ibnu Abbas bergegas menyediakan air wudlu buat Rasulullah. Siti Maimunah memberitahukan pada beliau, "Ibnu Abbas telah menyediakan air wudlu buatmu, wahai Rasul". Seketika itu, Rasulullah memanjatkan doa buat Ibnu Abbas, berupa "Allahumma Faqqihhu fi al-Din wa 'Allimhu al-Ta'wil". Lihat; Gānim Qaddūìi al-Hamad, Muhādarāt fí 'Ulüm al-Qur'ān (Amman: Dar 'Ammar, 1423), 172. Bandingkan; Ibnu Hajar al-‘Asqalānì, Fath al-Bārī, Juz I (Beirut: Dār al-Fikr, t.th.), 169. 
Potret epistemologi tafsir era formatif (peta kajian tafsir klasik perspektif filsafat ilmu)

mereka mendapatkan kesulitan dalam memahami ayat-ayat suci alQur'an.

Namun sekalipun cukup intensif dalam menafsirkan al-Qur'an, hasil dari keseriusannya tidak terdokumentasikan secara utuh sebagaimana layaknya kitab-kitab tafsir yang ada sekarang. Sebab beliau hanya menafsirkan dalam bentuk oral (riwayat) yang dapat ditemukan dalam bentuk kompilasi kumpulan tulisan mufassir berikutnya semisal Ibnu Jarir al-Ṭabari, Ibnu Kathïr dalam karyanya dan Imam al-Suyưti, ${ }^{34}$ termasuk juga upaya serius yang dilakukan oleh Fairuzzabadi dalam kitab tafsirnya yang berjudul Tanwìr al-Miqbās min Tafsìr Ibn Abbās.

Dalam konteks yang demikian, pada point ini penulis akan menguraikan secara detail terkait dengan aplikasi teori penafsiran Ibnu Abbas di atas yang dapat diklasifikasikan menjadi empat bagian, yaitu:

Pertama, al-Qur'an dengan al-Qur'an. Ibnu Abbas meyakini bahwa al-Qur'an dapat menafsirkan al-Qur'an yang lain. ${ }^{35}$ Keyakinan semcam ini dipraktikkan oleh Ibnu Abbas ketika beliau menafsirkan Qs. al-Mu'min: 11. Dalam ayat ini, menurut Ibnu Abbas bahwa manusia dihidupkan dan dimatikan sebanyak dua kali, yaitu ketika dihidupakan pertama kali dan sewaktu di bangkitkan pada hari kiamat kelak. Demikian pula, manusia dimatikan sebanyak dua kali yaitu pada saat masih diciptakan dari tanah dan sewaktu masuk dalam liang kubur. Penafsiran semacam ini menggunakan bantuan informasi dari QS. al-Baqarah: $28 .^{36}$

Kedua, al-Qur'an dengan al-Sunnah. Misalnya, ibnu Abbas menafsirkan QS. al-Baqarah: 116 dengan bantuan sunnah Nabi. Dalam konteks ini, Nabi menjelaskan bahwa Allah swt berfirmana; "Anak cucu Adam as mendustai dan mencela-Ku yang seharusnya hal itu tidak boleh terjadi. Pendustaan itu lantaran mereka menganggap-Ku tidak bisa mengembalikan (menghidupkan) kembali seperti sediakala, sedang pencelaannya lantaran mereka mengatakan bahwa aku punya

\footnotetext{
${ }^{34}$ Ganim Qaddurì al-Hamad, Muhādarāt fì 'Ulūm al-Qur'ān,.....174.

${ }^{35}$ Metode intertekstualitas ini, menurut mayoritas mufassir merupakan langkah yang paling ampuh dalam mengungkap dan menyingkap maksud ayat al-Qur'an. Sebab sang pembicara yang dalam hal ini adalah Allah- pasti lebih mengetahui dan mengenal maksudnya dari pada yang lain. Lihat; Muhammad Husain al-Dhahabi, al-Tafsir wa al-Mufassirün,.... 37.

36al-Ṭabarì, Jāmi' al-Bayān 'an Ta’wīl Āyi al-Qur'ān, Juz I (Kairo: Dār al-Ma'ārif, tth.), 419.
} 
anak. Sungguh, maha suci Aku dari segala tuduhan mereka tentang diriku yang membutuhkan sahabat atau punya anak". ${ }^{37}$

Ketiga, al-Qur'an dengan Syair Arab Kuno. al-Qur'an menyatakan dirinya sebagai kitab suci yang diturunkan menggunakan bahasa Arab (Qur'ānan 'Arabiyyan). ${ }^{38}$ Kalupun di dalamnya terdapat kosa kata non arab (laisat 'arabiyyatan), misalnya kata-kata asing (garib), tidak berarti menunjukkan "impotensi" pernyataan di atas dikarenakan kosa kata asing tersebut hanya digunakan dalam jumlah yang relatif terbatas. ${ }^{39}$ Selain itu, kosa kata asing yang digunakan dalam al-Qur'an -sebagaimana yang terjadi dalam perkembangan bahasa-bahasa dunia- sudah mengalami proses transliterasi (mu'ākhadzah) dan assimilisasi (muwāfaqah). ${ }^{40}$ Namun meski demikian, kondisi tersebut tidak menyurutkan upaya Ibnu Abbas untuk menginterpretasikan al-Qur'an. Optimisme beliau berangkat dari pengalaman kecerdasan beliau dalam bidang kesusasteraan Arab sehingga membawa implikasi pada satu kesadaran bahwa dalam menghadapi kasus demikian, alat interpretatif yang paling "ampuh" untuk mengurai kesulitan (mushkilah) aspek semantik tersebut, salahsatunya yaitu syair-syair Arab kuno. ${ }^{41}$

Sebut saja misalnya, ketika Ibnu Abbas berhadapan dengan kosa kata "al-Ithmu", maka beliau menafsirkannya dengan pengertian khamr (sesuatu yang memabukkan), berdasarkan informasi syair Arab. ${ }^{43}$ Demikian pula, menurut pengakuan Ibnu Abbas sendiri

${ }^{37}$ Imam Bukhārī, Sahīh al-Bukhārī, Juz VI, bab Kitab Tafsir, h. 24.

${ }^{38}$ Dalam hal ini, al-Qur' an menyatakan dengan redaksi "Qur'anan 'Arabiyyan" dan "bi Lisanin 'Arabiyyin". Lihat selangkapnya; QS. Yūsuf: 02 dan QS. al-Syu'arā': 195.

${ }^{39}$ Abd al-Qādir Muhammad Șālih, al-Tafsìr wa al-Mufassirūn,.... 83.

40، Adnan Muhammad Zarzùr, 'Ulūm al-Qur'an̄: Madkhal ila Tafsìr al-Qur'ān wa Bayānu I'Jäzihī (Beirut: al-Maktab al-Islamī, 1401), 399.

${ }^{41}$ Dalam konteks ini, Ibnu Abbas pernah berkata, "Jika kalian bertanya padaku tentang katakata asing dalam al-Qur'an, maka hendaklah kalin berpegang teguh pada syair, sebab syair itu adalah murni bahasa Arab (diwān al-Arab). Lihat; al-Qurțubī, al-Jāmi' li Ahkām al-Qur'ān, Juz I, (Kairo: Dār al-Kutub al-'Arabī, 1387), 24. Lihat juga; Shihāb al-Dīn Maḥūud bin

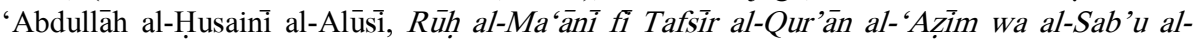
Mathānī, Juz XVI (Bierut: Dār al-Kutub, 1415), 250. Lihat juga, Muhyiddin al-Darwisīi, I'rāb al-Qur'ān Wa Bayānuhū, Juz V (Syiria; Dār al-Irshād, t.th.), 306.

${ }^{42}$ Kata al-Ithmu yang ditafsirkan Ibnu Abbas adalah kata yang terdapat dalam QS. al-A'rāf: 33.

${ }^{43}$ Ibnu Abbas mengutip sebuah Syair, "Sharibtu al-Ithma hattā ḍalla 'aqIì wa Kazhālika alIthmu tazhhabu bi al- 'Uqül' (Aku meminum khamr hingga sesat akalku Demikianpula khamr menyebabkan hilangnya akal orang lain". Lihat; Abū TTāhir Ibn Ya'qūb al-Fairuzabadi, Tanwïr al-Miqbās min Tafsìr Ibn 'Abbās (Beirut: Dār al-Fikr, t.th.), 101. 
Potret epistemologi tafsir era formatif (peta kajian tafsir klasik perspektif filsafat ilmu)

bahwa dulu, beliau tidak mengetahui apa arti dari al-Fätihịin, ${ }^{44}$ namun ketika pada suatu hari beliau mendengar Putri Dzi Yazan al-Humairi berkata, "Ta'āl Ufätiḥuka ay Uqădika (kemarilah! Aku akan memberikan keputusan padamu), barulah beliau sadar bahwa kata fătihin berarti pemberi keputusan. ${ }^{45}$ Demikian pula dengan kata fătir. Ibnu Abbas dengan mudah menggunakan bantuan perkataan salah seorang arab badui (pedalaman) yang mengartikan "menciptakan pertama kali". 46 Sedangkan kosa kata "al-Rafathu" 47 beliau menafsirkannya dengan kata "al-Jimā', ${ }^{48}$ Hanya saja, dalam konteks ayat ini, lanjut Ibnu Abbas, kata tersebut dibentuk kata kināyah oleh Allah.

Keempat, al-Qur'an dengan cerita Israiliyyat (al-Ahädith alIsrä'iliyyāt). Menurut cerita al-Qur'an, ${ }^{49}$ setiap rasul dan kitab yang dibawanya merupakan dua entitas yang sama-sama mempunyai visi dan misi untuk membenarkan (musaddiq) dan memperkuat (mu'ayyad) dua entitas -rasul dan kitab- sebelumnya. Dalam konteks ini, kehadiran Nabi Isa as dengan kitab Injilnya untuk membenarkan misi kerasulan Nabi Musa serta kitab Taurat yang dibawanya. ${ }^{50}$ Demikian pula, kedatangan Nabi Muhammad bersama kitab sucinya al-Qur'an, tentu saja juga mempunyai misi yang sama, yaitu membenarkan dan memperkuat kitab-kitab sebelumnya.

Berangkat dari fenomena ini, sudah bisa dipastikan bahwa tema-tema yang diusung dalam al-Qur'an tentu saja tidak jauh berbeda dengan tema yang diangkat oleh kitab-kitab sebelumnya. Salah-satu di antaranya adalah tema tentang kisah-kisah para nabi dan kisah ummat-ummat terdahulu (al-Umam al-Gäbirah). Hanya saja, style dan metode yang digunakan dalam penyampaian tema-tema

\footnotetext{
${ }^{44} \mathrm{QS}$. al-'A'rāf: 89. Rabbanā iftah bainanā wa qauminā,....

${ }^{45}$ Nur al-Dīn 'Itr, 'Ulüm al-Qur'ān, Juz I (Damaskus: Matba'ah al-Sabah, 1414), 256.

${ }^{46}$ Narasi lengkapnya sebagai berikut, "Ibnu Abbas berkata, "Dahulu aku tidak paham arti dari ayat "fätir al-Samāwati wa al-Arḍ'. Namun pada suatu ketika, saya sengaja mendatangi dua orang Arab yang sedang berselisih saling memperebutkan suatu sumur. Dari salah satu keduanya, saya mendengar perkataan, "ana fitratuhä" yang berarti "saya yang membuatnya pertama kali”. Lihat selengkapnya; al-Suyūțì, al-Itqān fì 'Ulūm al-Qur'ān, Juz I (Beirut: Dār al-Fikr, t.th.), 204. Bandingkan; Muhammad Abū Shuhbah, al-Madkhal li Dirāsāt al-Qur'ān al-Karim, Juz I (Kairo: Maktabah al-Sunnah, 1423), 31.

${ }^{47}$ QS. al-Baqarah: 187.

${ }^{48}$ al-T Tabari, Jämi' al-Bayān 'an,...... Juz III, 487.

${ }^{49}$ Lihat selengkapnya; QS. al-Māidah: 46; QS. al-An’ām: 92; QS. Fātir: 31; QS. al-Baqarah: 97; dan QS. al-Ahqāf: 30.

${ }^{50}$ Ramzi Na'na'ah, al-Isrā'iliyyāt wa Atharuhā fi Kutub al-Tafsìr (Damaskus: Dār al-Qalam, 1390), 26-27.
} 
Potret epistemologi tafsir era formatif (peta kajian tafsir klasik perspektif filsafat ilmu)

tersebut, al-Qur' an mempunyai karakteristik tersendiri yang nota bene jauh berbeda dengan gaya penuturan yang disampaikan dalam kitabkitab samawi lainnya. ${ }^{51}$ Artinya, sajian cerita yang dipaparkan alQur'an, biasanya menggunakan metode global dan tidak detail. Misalnya, al-Qur'an tidak mengupas secara tuntas terkait dengan unsur-unsur intrinsik ${ }^{52}$ suatu kisah yang sedang ditampilkannya karena al-Qur'an bukanlah buku sejarah yang hendak menceritakan suatu kisah secara naratif-kronologis. ${ }^{53}$

Dalam kondisi yang demikian, ketika al-Qur'an tidak mendeskripsikan secara tuntas, belum lagi tidak ditemukannya informasi pendukung dari Nabi Muhammad, maka bukan sesuatu yang aneh jika kemudian ada sebagian para sahabat nabi yang -meminjam bahasa dari Husaīn al-Dhahabī- dengang sangat terpaksa (bi alDarürah) $)^{54}$ bersikap oportunis untuk menggali informasi dari para ahli kitab yang telah masuk Islam, termasuk "proyek penafsiran" yang dilakukan oleh Ibnu Abbas sendiri.

Penggalian informasi melalui bantuan dari para ahli kitab yang telah masuk Islam, semisal Ka'ab al-Ahbār, Wahab bin Munabbih dan Abū al-Jilid, seringkali dijadikan pijakan dan referensi oleh Ibnu Abbas dalam menghadapi ayat-ayat yang bertemakan kisah-kisah, berita seputar orang-orang masa lampau, serta tema-tema hukum yang ada relevansinya antara al-Qur'an dengan Taurat dan Injil. Namun jika yang terjadi sebaliknya, misalnya terkait dengan ayat-ayat teologis yang tidak relevan dan akurat antar keduanya, maka sikap

\footnotetext{
${ }^{51}$ Muhammad Husaīn al-Dhahabī, "“'Ilmu al-Tafsir" dalam Buhüth fì 'Ulüm al-Tafsìir wa alFiqh wa al-Da'wah (Kairo: Dār al-Hadith, 1426), 394.

${ }^{52}$ Unsur Intrinsik adalah merupakan unsur-unsur yang membangun dari dalam karya sastra itu sendiri, misalnya terkait dengan tema, setting, plot, penokohan, point of view, pesan dan gaya bahasa. Lihat selengkapnya; Fathurrosyid, Semiotika Kisah al-Qur'an; Membedah Perjalanan Religi Raja Sulaiman dan Ratu Balqis dalam al-Qur'an (Surabaya: Pustaka Radja, 2013), 44.

${ }^{53}$ Ruang-ruang kosong dalam unsur intrinsik ini hemat penulis menjadi entry point bagi sosok Muhammad Ahmad Khalafullah untuk melegitimasi asumsi dan paradigma yang dibangunnya, bahwa al-Qur'an bukanlah kitab ensiklopedi sejarah. Paradigma ini dibeberkan semuanya dalam karya magnum opus-nya yang berjudul al-Fann al-Qașași fí al-Qur'ān alKarīm. Lihat selengkapnya; Muhammad Aḥmad Khalafullah, al-Fann al-Qasașī fí al-Qur'ān al-Karim, (Kairo: Maktabah al-Nahḍah al-Mișriyyah, 1951).

${ }^{54}$ Pernyataan bi al-Darürah ini mengingat status hukum meriwayatkannya sangat kompleks sesuai petunjuk al-Qur'an dan instruksi nabi. Pertama, menolak israiliyyat jika terjadi kontradiksi dengan al-Qur'an dan sunnah yang sahih. Kedua, menerimanya. Ketiga, dibutuhkan sikap antisipatif (mauqif al-Hazr) dan netralitas (al-Hayad). Lihat selangkapnya; Muhammad Husain al-Dhahabī, "al-Isrā'iliyyat fí al-Tafsìr wa al-Hadith" dalam Buhüth fí 'Ulüm,.....35-47. Lihat juga; Muhammad bin Lutfî al-Sabāgh, Lamhät fì 'Ulüm al-Qur'ān wa Ittijāhāt al-Tafsìr (Beirut: al-Maktab al-Islāmī, 1410), 265.
} 
Potret epistemologi tafsir era formatif (peta kajian tafsir klasik perspektif filsafat ilmu)

resistensi merupakan pilihan utama yang dirasa oleh Ibnu Abbas untuk menganulirnya. ${ }^{55}$ Hal ini dikarenakan dalam kitab Taurat dan Injil, mayoritas substansinya sudah terjadi distorsi dan perubahan di sana-sini.

Terkait dengan hal ini, Ibnu Abbas pernah mengimplementasikan kisah israiliyyat pada ayat "wa utruk al-Bahra rahwān" "s6 dengan meminta penjelasan dari Ka'ab al-Ahbar yang mengatakan bahwa arti dari "al-Bahra rahwān" adalah jalan yang basah. ${ }^{57}$ Demikian pula, ketika Ibnu Abbas berhadapan dengan ayat "fa kāna li gulamaini yatimaini", maka dengan sangat mantap Ibnu Abbas menafsirkan dengan dua anak yatim yang bernama Asrūm dan Sārim di suatu kota yang bernama Antaqiyyah. ${ }^{58}$

Kelima, al-Qur'an dengan Asbāb al-Nuzūl. al-Qur'an diturunkan oleh Allah tidak berada dalam ruang kosong dan tidak pernah muncul dalam vacum cultural. Ia merupakan bentuk respon Allah pada kondisi budaya dan sosio-kultural ketika diturunkannya. Fenomena ini-lah kemudian menjadi asumsi dasar para ulama dan sarjana muslim, ${ }^{59}$ bahwa mengetahui dan mempelajari situasi kesejarahan al-Qur'an menjadi sesuatu yang -dalam terminologi ilmuilmu al-Qur'an disebut Asbāb al-Nuzūl- sangat urgen untuk memperoleh weltanschaung al-Qur'an. ${ }^{60}$

\footnotetext{
${ }^{55}$ Realita ini merupakan indikasi konkrit atas sikap netralitas-objektivitas Ibnu Abbas terhadap kisah Israiliyyat selama berdasarkan data valid dan akurat. Sebab dalam satu momen, Ibnu Abbas pernah menunjukkan sikap simpatinya untuk menggali informasi dari para ahli kitab, seperti yang telah dipraktikkannya, namun dalam kesempatan yang lain, beliau justeru dengan tegas dan "garang" menampakkan sikap antipatinya. Selektifitas sikap Ibnu Abbas ini, hemat penulis telah mematahkan tesis Ignaz Goldziher dan Ahmad Amin yang telah mengklaim Ibnu Abbas sebagai penafsir al-Qur'an yang bebas merujuk pada ahli kitab. Lihat selengkapnya; Muhammad Husaīn al-Dhahabī, al-Tafsir wa al-Mufassirūn,..... 71-72.

${ }^{56} \mathrm{QS}$. al-Dukhān: 24.

${ }^{57}$ al-Suyūtịi, al-Dur al-Manthūr, Juz VI (Beirut: Dār al-Ma'rifah, t.th.), 29.

${ }^{58} \mathrm{Abu}$ Tāhir Ibn Ya'qūb al-Fairuzabadi, Tanwìr al-Miqbās,....., 70.

${ }^{59}$ Lihat misalnya pernyataan Ibnu Taymiyah dan Ibnu Daqiq al- ${ }^{-} \mathrm{I} d$. Lihat; Muhammad Ali alSabūnī, al-Tibyān fì 'Ulūm al-Qur'ān (Beirut: Dār al-Kutub al-Islamiyyah, 1424), 21.

${ }^{60}$ Namun betapapaun urgennya pengetahuan tentang historisitas suatu ayat (sabab nuzul) sebagaimana pernyataan Ibnu Taimiyah, pengetahuan tersebut bukan satu-satunya "primadona" dalam menafsirkan. Hal ini disebabkan, setelah dilakukan penelitian terhadap karya al-Wāhidi dalam kitab Asbāb al-Nuzūl, ternyata dari semua jumlah ayat yang ditampilkan dalam karya tersebut, diperoleh suatu konklusi bahwa ayat yang tidak dapat dipahami dengan sempurna kecuali melibatkan konteks historisnya hanya berjumlah 8 ayat yang tersebar dalam 6 surat; yaitu QS. al-Baqarah: 115, 158 dan 195; QS. Ali Imrān: 188; QS. al-Māidah: 93; QS. al-Dukhān: 49; QS. al-Taghābun: 14 dan QS. al-Talāq: 4. Lihat
} 
Sebagai mufassir, Ibnu Abbas juga sangat apreseatif terhadap konteks kesejarahan al-Qur'an, sehingga beliau sangat intens bertanya dan berkonsultasi pada sahabat senior yang lebih mengetahui tentang sabab nuzul suatu ayat. Kondisi ini terlihat, misalnya ketika Ibnu Abbas menafsirkan QS. al-Tahrim: 04. Pada kasus ayat ini, ternyata menurut Ibnu Abbas bahwa "oknum" dibalik aksi boikot isteri-isteri Nabi adalah Hafșah dan Siti Aishah. ${ }^{61}$

Perhatian Ibnu Abbas terhadap Sabab Nuzul, juga diimplementasikan pada QS. al-Baqarah: 26-27. ${ }^{62}$ Menurut Ibnu Abbas, bahwa ayat ini diturunkan oleh Allah dalam rangka merespon aksi protes orang-orang munafik yang diumpamakan oleh Allah laksana orang yang menyalakan api, tetapi setelah api itu menerangi sekelilingnya, Allah hilangkan cahaya (yang menyinari) mereka, dan membiarkan mereka dalam kegelapan, tidak dapat melihat, ${ }^{63}$ atau seperti (orang-orang yang ditimpa) hujan lebat dari langit disertai gelap gulita, guruh dan kilat; mereka menyumbat telinganya dengan anak jarinya, karena (mendengar suara) petir, sebab takut akan mati.

Demikian pula, pengetahuan Ibnu Abbas tentang konteks historis suatu ayat yang meliputi konteks geografis, ${ }^{64}$ perjalanan Rasulullah dan nāsikh-mansükh ${ }^{65}$ semakin menunjukkan akan kredebilitas kecerdasan dan intensitas beliau bersama dengan sahabat senior, semisal Sayyidina Umar bin al-Khaț̣āb yang senantiasa memberi support dan memotivasi Ibnu Abbas agar senantiasa bergelut di bidang ini.

Keenam, al-Qur'an dengan Ijtihad. Ibnu Abbas juga pernah menafsirkan al-Qur' an menggunakan logika murni, yaitu menafsirkan al-Qur'an dengan cara mengurai makna dibalik teks berdasarkan pada

selengkapnya; Nasrulloh, Ayat Ayat Al-Qur'an Yang Tidak Dapat Difahami Tanpa Historisitasnya (Sabab Al-Nuzul), Tesis IAIN Sunan Ampel Surabya, 2009.

${ }^{61}$ Penafsiran ini, beliau peroleh dari Sayydinina Umar bin Khttab. Lihat; al-Qinnauji, Fath alBayān fí Maqāsid al-Qur'ān, Juz I (Beirut: al-Maktabah al-‘Asriyyah, 1412), 25.

${ }^{62}$ al-Wāhidi, Asbāb al-Nuzūl,.....23.

${ }^{63}$ QS. al-Baqarah: 17.

${ }^{64}$ Misalnya pernyataan Ibnu Abbas, bahwa QS. al-An'ām, kesemuanya diturunkan pada malam hari di kota Mekkah yang dikelilingi tujuh puluh ribu malaikat sembari mengucapkan tasbih. Lihat; Ibnu Kathir, Tafsìr al-Qur'ān al- 'Azìm, Juz II (Beirut: Dār Ihya', t.th), 122.

${ }^{65}$ Menurut Ibnu Abbas, QS. al-Taubah: 42, diturunkan pada saat Nabi berada di perang Tabuk. Lihat: al-Suyūți, al-Itqān fí Ulūm al-Qur'ān, Juz I, h. 25. Adapun yang dimaksud dengan Nasikh-Mansuk di sini yaitu kapabilitas Ibnu Abbas tentang sabab nuzul ayat yang dinasakh pertama kali adalah arah Kiblat yang terekam dalam QS. al-Baqarah: 142. Lihat; alWāhidi, Asbab,....21. 
Potret epistemologi tafsir era formatif (peta kajian tafsir klasik perspektif filsafat ilmu)

ijtihad lantaran kecerdasan dan ketajaman mata hatinya ${ }^{66}$ Praktek menggunakan penalaran semacam ini terlihat jelas ketika Ibnu Abbas menafsirkan QS. al-Qadr ${ }^{67}$ dan QS. al-Nassr ${ }^{68}$ yang nota bene cara kerja interpretasi beliau terhadap teks justeru melompat jauh dan berbeda dengan pemahaman mainstream yang ada, sehingga menjadikan sosok Sayyidina Umar terkagum-kagum atas pemahamannya.

Tentu saja, tindakan interpretasi Ibnu Abbas yang melompat jauh dari level teks tersebut diyakini imam al-Shătibì dan Husain alDhahabi ${ }^{69}$ sebagai embrio dan legalitas bagi kemunculan genre tafsir yang -dalam kajian ilmu-ilmu al-Qur'an- disebut tafsir isyari atau tafsir simbolik ${ }^{70}$ yang banyak dimanfaatkan oleh kelompok sufisme. Asumsi dasar yang dijadikan pijakan legalitas kinerja penafsiran mereka adalah berangkat dari pernyataan Rasulullah saw, ${ }^{71}$ bahwa setiap ayat al-Qur'an mempunyai struktur makna zahir dan struktur makna batin. ${ }^{72}$

\footnotetext{
${ }^{66}$ Kecerdasan Ibnu Abbas terkait hal ini terbukti dengan adanya pengakuan Sayyidina Ali yang mengatakan bahwa, Ibnu Abbas seakan-akan dapat menyingkap hal-hal yang metafisik. Lihat selengkapnya; Abd al-Jawād Khalaf Muhammad Abd al-Jawād, Madkhal ilā al-Tafsìr wa 'Ulüm al-Qur'ān, Juz I (Kairo: Dār al-Bayān al-Arabì, t.th.), 78.

${ }^{67}$ Ketika Sayyidina Umar ra mengumpulkan para sahabat Nabi dan menanyakan perihal turunnya malam lailatul qadar. Dari semua sahabat yang hadir, hanya Ibnu Abbas yang dapat menjelaskan secara argumentatif dan Umar memujinya. Menurut Ibnu Abbas, malam lailatul qadar turun pada setiap tanggal yang berangka tujuh (07) di malam Ramadan, sebab Allah menciptakan langit dan bumi, jumlah hari dan bulan, penciptaan manusia, sujud, țawaf dan melempar jumrah, kesemuanya berjumlah tujuh kali. Lihat; Ibu Kathïr, Tafsir al-Qur'ān alAzim, Juz IV, .... 262

${ }^{68}$ Secara tekstual, QS. al-Nașr: 1-4 merupakan perintah Allah pada Nabi saw. agar beliau membaca tasbih dan bersyukur atas karunia-Nya yang telah melimpahkan nikmat berupa pertolongan sehingga banyak orang yang masuk Islam secara berbondong-bondong. Namun, bagi Ibnu Abbas, seluruh ayat ini justeru merupakan sinyal kuat atas detik-detik terakhir kebersamaan para sahabat dengan Nabi. Lihat selengkapnya; Muhammad Nur al-Din 'Itr, 'Ulüm al-Qur'ān,..... 98.

${ }^{69}$ Muhammad Husaīn al-Dhahabi, Ibnu 'Arabī wa Tafsir al-Qur'ān; Haqiq al-Tafsìr alMansūb Ilaihi (Kairo: Dār al-Hadith, 1426), 223.

${ }^{70}$ Menurut al-Shătibī, tafsir simbolik ini bisa diterima dengan beberapa syarat: Pertama, tidak mengeleminir makna lain dan mengakui sebagai satu-satunya makna. Kedua, tidak menimbulkan kerancuan terhadap penafsirannya. Ketiga, menjelaskan dan menguraikan makna lain yang digunakan dalam al-Qur'an. Muhammad Salim Abu 'Āṣī, 'Ulūm al-Qur'ān 'inda al-Shätibì, Juz I (Kairo: Dār al-Basāir, 1426), 81.

${ }^{71}$ al-Suyūți, al-Itqān fì 'Ulūm al-Qur'ān, Juz II,...486

${ }^{72}$ Hadis ini, dinilai daif oleh Ibnu Taimiyah, karena hadis tersebut merupakan perkatan Hasan al-Bașrīi. Lihat selengkapnya; Hamād bin Sālih, Muhādarāt fí 'Ulüm al-Qur'ān, Juz I (Ammān: Dār Ammār, 1423), 255.
} 
Potret epistemologi tafsir era formatif (peta kajian tafsir klasik perspektif filsafat ilmu)

\section{b. Aplikasi Tafsir Abdullah bin Mas'ud}

Sebagaimana diketahui, Ibnu Mas' $\mathrm{ud}^{73}$ adalah salah-satu sahabat yang paling cerdas dalam bidang qirāăh dan nāsikhmansükh, ${ }^{74}$ sehingga tidak heran jika Rasulullah pada suatu waktu pernah mengalirkan air mata pada saat meminta dan mendengarkan indahnya bacaan Mas'ud. Beliau termasuk sahabat yang cerdas dalam bidang penafsiran al-Qur'an, Asbāb al-Nuzūl dan paling serius mencari informasi terkait bidang tersebut. ${ }^{75}$

Merujuk pada informasi di atas, kiranya menjadi sesuatu yang penting bagi penulis untuk menguraikan tentang metode tafsir yang digunakan oleh Ibnu Mas'ūd yang dapat dikategorikan menjadi beberapa metode, yaitu; Pertama, al-Qur'an dengan al-Qur'an. Metode intertekstualis ini banyak dipalikasikan oleh Ibnu Mas'ūd. Kedua, al-Qur'an dengan bantuan informasi sunnah. Ini seperti penafsiran beliau pada kata Salat al-Wusta ${ }^{-76}$ yang ditafsirkan dengan salat Asar, dengan cara merujuk pada hadis Nabi. ${ }^{77}$ Ketiga, sabab nuzūl. Point ini mendeskrisikan akan perhatian beliau dengan cara meminta informasi dari sahabat yang terlibat langsung dengan sabab nuzul. Misalnya, pada QS. al-Taubah: 113, menurut Mujāhid terkait dengan permohonan Rasulullah di kuburan ibunya, Siti Aminah binti Wahab. ${ }^{78}$

Keempat, perhatian Mas'ud pada ayat-ayat muhkamät dan mutashābihāt. Misalnya, pernyataan Ibnu Masud bahwa QS. al-Nisā': 93 merupakan ayat muhkamät. Kelima, pengetahuannya tentang

\footnotetext{
${ }^{73}$ Nama lengkapnya adalah Abdullah bin Mas'ūd bin Gāfil. Beliau diberi predikat dengan sebutan Abū Abdurrahmān al-Hadhali. Lihat; Muhammad Husaīn al-Dhahabī, al-Tafsìr wa alMufassirūn,..... 83.

${ }^{74} \mathrm{Hal}$ ini diakui oleh Ibnu Abbas sendiri bahwa beliau salah-seorang yang mendampingi Rasulullah pada saat mengulang bacaan Qur'an di hadapan malaikat jibril. Lihat; Ibid.,

${ }^{75}$ Diceritakan dari Masrūq, Ibnu Mas'ūd berkata, "Demi zat yang tidak ada Tuhan selain-Nya, tidak ada satu ayat pun dari al-Qur' an yang diturunkan kecuali aku mengetahui kepada siapa ayat itu diturunkan dan di mana diturunkan, jika aku mengetahui ada seseorang yang lebih tahu dariku, maka aku akan mendatanginya". Lihat; Ibid.,

${ }^{76}$ QS. al-Rahmān: 72:

${ }^{77}$ al-Suyūtịi, al-Dur al-Manthūr fí Tafsìr bi al-Ma'thūr, Juz III (Mesir: Dār Hajr, 1424), 84.

${ }^{78}$ Pada suatu ketika, Rasulullah pergi menuju suatu kuburan dan kami ikut dibelakangnya hingga sesampainya di tempat tersebut, setelah beberapa lama kemudian, kami mendapati Rasulullah sedang menangis. Umar bin Khattab bertanya, Hai Rasul, apakah gerangan yang membuat dirimu menangis sehingga air mata kamipun juga ikut mengalir? Rasul menjawab, "Di tempat kuburan yang aku menangis itu adalah kuburan ibuku, Aminah binti Wahab. Di sana tadi aku memohon pada Allah agar dosa-dosa ibuku diampuni-Nya, tapi permohonan itu ditolak". Kemudian turunlah ayat tersebut. Lihat selengkapnya; al-Wāhidi, Asbāb al-Nuzūl, Juz I,.... 178.
} 
Potret epistemologi tafsir era formatif (peta kajian tafsir klasik perspektif filsafat ilmu)

halal-haram. Ini didasarkan pada suatu ayat ${ }^{79}$ yang menurut Ibnu Abbas merupakan ayat perintah menghalalkan yang halal dan mengharamkan yang haram. Karena itu, Masud senantiasa memberikan fatwa keagamaan pada masyarakat. Misalnya, penafsiran Abdullah pada QS. al-Qur'an: 233 yang menyatakan bahwa tidak dinamakan radāa ah lagi bagi seorang anak yang telah sampai pada usia dua tahun atau masa menyapih, ${ }^{80}$ serta juga penafsiran beliau tentang ila ${ }^{81}$ yang apabila telah sampai empat bulan, maka status isterinya menjadi perempuan yang tertalak seacara bain. ${ }^{82}$

Keenam, perhatian Ibnu Mas'ùd tentang Qirāàt. Misalnya bacaan Ibn Mas'ūd yang berbunyi, aw yakūna laka baytun min dhahab memperjelas maksud dari bacaan resmi al-Qur'an yang berbunyi $a w$ yakūna laka baytun min zukhn̄f (atau hingga kamu mempunyai rumah dari emas) QS. al-Isrā' [17]: 93. Kata Zukhrūf ditafsirkan dengan dhahab, yang konon dulu Imām Mujāhid tidak mengetahui arti kata $z u k h r u ̄ f$ sebelum membaca qiră'ah Ibn Mas'ūd. ${ }^{83}$ Demikian pula perlakuan Ibnu Mas'ud pada QS. al-Maidah: 38 yang menurut versi bacaan beliau berupa "wa al-Säriqūna wa al-Sāriqātu fa iqta'ū aimānuhum", sehingga membuat para mufassir berikutnya, semisal alZamakhshāri dan Imām Nawawi Banten menafsikan pemotongan tangan seorang pencuri yang pertama kali adalah pada tangan kanannya. ${ }^{84}$ Demikian pula pada kata wa fumiha ${ }^{85}$ yang dalam versi

\footnotetext{
${ }^{79}$ QS. al-Baqarah: 121. Menurut Ibnu Mas'ūd, maksud membaca ayat al-Qur'an yang sebenarnya sebagaimana terekam dalam ayat "yatlūnah $\bar{u}$ haqqa tiläwatih $\vec{i}$ yaitu menghalalkan yang halal dan mengharamkan yang haram dan memembacanya sesuai dengan yang diturunkan oleh-Nya, tidak mengubah kalimat dari konteksnya dan tidak menafsirkan yang tidak sesuai dengan kehendak-Nya. Lihat: al-Ṭabari, Jämi' al-Bayān,....Juz II, 569. alSuyūtî, al-Dur al-Manthür,.....Juz I, 576-7. ${ }^{80}$ al-Ṭabarì, Jāmi' al-Bayān,......Juz III, 56.

${ }^{81}$ QS. al-Baqarah: 226. Kata Ilä, menurut ahli fikih secara terminologi adalah sumpah yang diucapkan seorang suami yang tidak akan melakukan hubungan seksual dengan isterinya dalam batas waktu tertentu. Lihat: Ibnu Rushd, Bidāyāt al-Mujtahid, Juz II, (Beirut: Dār Ma'rifah, t.th.), 99 .

${ }^{82}$ al-Ṭabari, Jāmi' al-Bayān,..... Juz VI, 49

${ }^{83}$ al-R̄āì, Mafătīh al-Gaib, Juz XI (Beirut: Dār al-Kutb, 1421), 49.

${ }^{84}$ Alasan Ibnu Mas'ud, karena Nabi juga mempraktikkan potong tangan kanan kasus pencurian Tu'mah. Lihat: Al-Zamakhshāri, al-Kashshāf 'an Haqà'iq Gawāmid al-Tanzīl wa 'Uyūn al-Aqāwīl fi Wujūh al-Ta'wìl, Juz I (Beirut: Dār al-Kitab, 1407), 632. Bandingkan; alNawawì al-Bantani, Marah Labīd li Kashfi Ma'nā al-Qur'ān al-Majìd, Juz I (Beirut: Dār alKutub, 1418), 267.

${ }^{85}$ QS. al-Baqarah: 61.
} 
Potret epistemologi tafsir era formatif

(peta kajian tafsir klasik perspektif filsafat ilmu)

qirā'ah Ibnu Mas'ud dibaca wa taumiha sehingga banyak dijadikan rujukan oleh penafsir baik di masanya maupun pasca beliau. ${ }^{86}$

\section{Epistemologi Tafsir Era Tabi'in; Model Nalar Quasi-Kritis}

Dengan berakhirnya masa sahabat, tradisi penafsiran dilanjutkan oleh generasi para tabi'in dengan pola yang relatif sama. Memang ada hal yang membedakan antara tradisi penafsiran era sahabat dengan era tabi'in. Di era sahabat belum muncul sektarianisme aliran-aliran tafsir yang tajam, sementara di era tabi'in sudah muncul aliran-aliran tafsir berdasarkan kawasan. Bahkan mulai muncul pula sektarianisme ideologi, seperti yang dinisbatkan kepada Imam Qatādah ibnu Di'āmah al-Sadūsì (w. 117 H ) yang dinilai berbau aliran Qadariyah, karena terlalu dalam ketika membahas masalah qaḍa qadar. Demikian pula Hasan al-Basri (w. $110 \mathrm{H}$ ) yang begitu tegas menetapkan adanya qada' dalam al-Qur'an, sehingga ia mengkafirkan pihak yang menolaknya. ${ }^{87}$

Secara geografis, paling tidak ada tiga aliran yang menonjol di era tabi'in, yaitu: Pertama, aliran Mekah, seperti Sa'id bin Jubaï (w. 95 H), 'Ikrimah (w. 104 H) dan Mujāhid ibn Jabr (w. 104 H ), 'Ațā' bin Abi Rabāh (w. $114 \mathrm{H}$ ), TTâwus (w. $106 \mathrm{H}$ ) dan lain-lain yang ketika itu mereka berguru kepada sahabat Ibn 'Abbās. Kedua, aliran Madinah, tokohnya antara lain Muhammad bin Ka'b (w. 118 H), Zayd ibn Aslam al-Qurazhỉ (w. 136 H), dan Abū 'Aliyah (w. $90 \mathrm{H}$ ) yang berguru kepada sahabat Ubay bin Ka'ab. Ketiga, aliran Iraq, tokoh-tokohnya antara lain Masrūq bin al-Ajda' (w. 163 H), Alqamah ibn Qays (w. $61 \mathrm{H}$ ), 'Āmir al-Sha'bi (w. 109 H), Hasan alBașrī (w. 110 H), Qatādah ibn Di'āmah al-Sadūsì (w. 117 H ), al-Aswād bin Yazid (w. $74 \mathrm{H}$ ). Mereka mengaku berguru kepada sahabat 'Abd Allah ibn Mas'ūd. ${ }^{88}$

Menurut Ibnu Taimiyah, tokoh-tokoh tafsir yang paling "hebat" dalam menafsirkan al-Qur'an adalah mereka yang berdomisili di Mekah, sebab mereka adalah murid-murid Ibn 'Abbas. ${ }^{89}$ Selain itu, aliran Mekah dan Madinah masih cenderung bercorak tradisionalis, dalam arti lebih banyak menggunakan riwāyat, sedangkan di Iraq mulai muncul corak tafsir bi ra'y (rasional). Boleh jadi hal ini disebabkan oleh karena kondisi geografis Irak yang cukup jauh dengan Madinah sebagai pusat studi hadis, sehingga mereka cenderung menggunakan ra'y ketika tidak menemukan riwayat. Di samping itu, secara politis tradisi penafsiran yang cenderung rasional itu

\footnotetext{
${ }^{86}$ Ibnu Kathīr, Tafsìr al-Qur'ān,.....Juz I, 280.

${ }^{87}$ Muhmmad Huusaīn al-Dhahabi், Al-Tafsìr wa al-Mufassinūn, Vol.1, 131.

${ }^{88}$ al-Zarqāni, Manāhil al-'Irfān,..... 275-276. Lihat juga: al-Qațtān, Mabāhith,..... 344.

${ }^{89}$ al-Zarqānì, Manāhil al-'Irfān,...... 275.
} 
Potret epistemologi tafsir era formatif (peta kajian tafsir klasik perspektif filsafat ilmu)

mendapat dukungan dari Gubenur 'Ammār bin Yāsir yang diangkat oleh khalifah 'Umar bin Khaț̣āb, yang notabene dikenal sebagai sahabat yang rasionalis. ${ }^{90}$

Di era tabi'in ini sudah terjadi semacam pergeseran mengenai rujukan penafsiran. Jika pada masa sahabat, mereka kurang begitu tertarik untuk menggunakan riwayat-riwayat isräiliyāt dari Ahli Kitab, maka tidak demikian dengan era tabi'in, yang sudah mulai banyak menggunakan sumber-sumber isrāiliyāt sebagai rujukan penafsiran, bahkan dijadikan sumber penafsiran secara ekstensif, terutama untuk penafsiran ayat-ayat yang berupa kisah, di mana al-Qur'an hanya menceritakannya secara global. ${ }^{91}$ Namun tesis yang demikian, ada yang menolaknya secara keras dan argumentatif. Ini disebabkan dalam realitanya, sumber israiliyyat yang dijadikan legitimasi penafsiran tabi' in masih sebatas yang pernah digunakan oleh sahabat. Sumber-sumber tersebut justeru lebih menjamur pasca tabi'in dan tersebar di berbagai literatur disiplin keilmuan, baik hadits maupun tafsir. $^{92}$

Dengan demikian, secara umum, sumber penafsiran pada masa tabi'in tidak ada perbedaan yang cukup siginifikan dengan sumber tafsir pada masa sahabat. Artinya, ketika para tabi'in berhadapan dengan ayat-ayat al-Qur'an, maka sumber referensi yang dijadikan rujukan mereka tidak jauh berbeda dengan rujukan para sahabat yang meliputi; Pertama, al-Qur'an. Kedua, sunnah nabi. Ketiga, pendapat sahabat. Keempat, lughat. Kelima, ahli kitab. Keenam, ijtihad (logika). ${ }^{93}$ Kecuali yang terakhir ini, hemat penulis justeru penggunaannya lebih leluasa jika dibandingkan dengan tafsir era sahabat mengingat kondisi sahabat yang tidak menafsirkan secara keseluruh ayatayat al-Qur'an.

\section{Aplikasi Model Tafsir Mujahid bin Jabar}

Mujāhid bin Jabar ${ }^{94}$ adalah seorang tokoh mufassir dari kalangan tabi'in dari madrasah Mekah yang belajar langsung pada gurunya, Ibnu

\footnotetext{
${ }^{90}$ al-Qaț̣̄an, Mabahith,..... 338-339.

${ }^{91}$ Faktor utamanya adalah banyaknya ahli kitab yang masuk islam dan para tabi'in ingin mencari informasi secara detail tentang kisah-kisah yang masih global dari mereka, seperti 'Abd Allah bin Salām, Ka'ab bin Akhbār, Wahb bin Munabbih, dan 'Abdul Mālik ibn 'Abdul 'Ażiz ibn Juraīj. Aḥmad Amīn, Fajr al-Islām (Kairo: Maktabah al-Nahụah al-Miṣriyah, 1975), 25 .

${ }^{92}$ Lihat selengkakpnya; al-Khuḍairi, Tafsir at-Täbi'inn, vol. 2,....964-965.

${ }^{93}$ Musaid bin Sulaimān al-Tayyār, Fusūl fì Usūl al-Tafsīr (Riyād: Dār al-Nashr al-Dauli, $1413), 35$.

${ }^{94}$ Mujāhid bin Jabar atau ada yang menyebut Mujāhid bin Jubair punya nama lengkap Abū alHujjāj Abū Muhammad al-Qurshì al-Makhzūmì al-Makki yang dilahirkan pada saat
} 
Potret epistemologi tafsir era formatif (peta kajian tafsir klasik perspektif filsafat ilmu)

Abbas. Beliau merupakan sosok yang paling "jago" dalam menafsirkan ayat al-Qur'an, sehingga membuat sosok Sufyan al-Thauri dengan mantap mengakui, bahwa jika ada suatu tafsir dari Mujāhid, maka cukuplah bagi kalian menerimanya saja. ${ }^{95}$

Popularitas Mujāhid bin Jabar di bidang tafsir dikarenakan keberanian ${ }^{96}$ beliau yang tidak mau menjadikan al-Qur' an sebagai kitab suci yang "berputar-putar" di atas langit, tetapi harus berdialektika dengan kondisi rill masyarakat ketika itu. Kondisi psikologi demikian tentu saja sangat jauh berbeda dengan psikologi yang dialamai oleh Said bin Jubair yang nota bene statusnya juga sama-sama murid Ibnu Abbas, bahkan termasuk murid yang paling banyak menerima tafsir dari sang maha guru. Namun karena sikap wira'inya ${ }^{97}$ - untuk tidak mengatakan sikap kekhawatirannya-, posisi beliau akhirnya tergeser dalam dunia penafsiran yang lebih didominasi oleh Mujāhid bin Jabar. Tidak heran jika kemudian, produk penafsirannya banyak dijadikan referensi oleh Imam Shäfi' ${ }^{i}$ dan Imam Bukhāri serta mufassir yang lain. ${ }^{98}$

Sebagai mufassir yang popular di mata masyarakat, tentu saja sikap pro-kontra terkait eksistensi Mujāhid bin Jabar adalah suatu keniscayaan. Ini terlihat adanya sebagian ulama yang justeru mempersoalkan kredebilitas beliau dari sisi israiliyyat sebagai sumber penafsirannya. ${ }^{99}$ Namun polemik tersebut tidak dapat memangkas "karier" Mujāhid di bidang tafsir lantaran sikap superioritas keadilan dan kejujurannya lebih dominan dari pada

pemerintahan Khalifah Umar bin al-Khattab yaitu tahu $21 \mathrm{H}$. Karier intelektual beliau berakhir pada saat pemerintahan Umar bin Abdul Aziz karena beliau meninggal dunia pada saat itu pula, yaitu tepat pada tahun $104 \mathrm{H}$ dalam usia 83 tahun. Lihat; Abu Muhammad alAsyūțì, Tafsir Mujāhid (Beirut: Dār al-Kutub al-Ilmiyyah, 2005), 5.

95 Abdullah bin Yūsuf al-Judaī', al-Muqaddimāt al-Asāsiyat fi 'Ulüm al-Tafsìr (Beirut: Muasasah al-Rayyan, 1422), 319.

${ }^{96}$ Keberanian Mujāhid sudah tampak semenjak beliau masih dalam bimbingan Ibnu Abbas. Ini terbukti dari cerita Ibnu Abi Malikah, bahwa ia dulu pernah melihat Mujāhid memohon pada Ibnu Abbas untuk belajar tentang tafsir dan Ibnu Abbas memberikan respon positif agar ia menulis semuanya. Lihat; Muhammad Saìd Ramaḍān al-Büți, Min Rawā'iu al-Qur'ān; Ta'ammalāt 'Ilmiyyah wa Adabiyyah fi Kitābillāh, Juz I (Beirut: Mu'asasah al-Risālah, 1420), 74.

${ }^{97}$ Sikap wirā’ $\bar{i}$ yang dimaksudkan di sini adalah keengganan Saìd bin Jubaïr menafsirkan dengan logika. Menurut cerita Ibnu Khalkān, Saìd bin Jubaiir menampakkan sikap "geram" ketika ada seseorang yang meminta kesediaan beliau agar menulis kitab tafsir, bahkan dengan nada emosi beliau menjawab, "saya lebih suka berada dalam kesulitan dan penderitaan dari pada harus melakukan proyek penafsiran". Lihat selengkapnya; Muhammad Husain alDhahabi, al-Tafsir wa al-Mufassirūn,.....102.

${ }_{98}$ Muhammad Husaīn al-Zahabī, al-Tafsìr wa al-Mufassirün,.....104. Bandingkan dengan; Abū Muhammad al-Asyūtî, Tafsìr Mujähid,..... 3.

${ }^{99}$ Abū Muhammad al-Asyūtịi, Tafsìr Mujāhid,..... 2. 
Potret epistemologi tafsir era formatif (peta kajian tafsir klasik perspektif filsafat ilmu)

sorotan inferioritasnya. Selain itu, komitmen Mujāhid yang sangat selektif terhadap sumber Israiliyyat, sebagaimana ideologi yang telah ditanamkan oleh gurunya, Ibnu Abbas, merupakan faktor kedua yang dapat menaikkan popularitasnya dalam dunia penafsiran.

Dengan demikian, dalam batas-batas tertentu, kreativitas Mujāhid dalam bidang tafsir, tentu tidak akan jauh berbeda dengan landasan pacu yang telah digunakan oleh gurunya sendiri. Kondisi yang demikian, dapat dibuktikan dengan beberapa model metode penafsiran yang digunakan oleh beliau, seperti di bawah ini:

Pertama, Tafsir Qur'an dengan Qur'an. Misalnya, QS. Fātir: 18 ditafsirkan dengan QS. al-An'ām: 164. Demikian pula, QS. al-'Ankabūt: 13 ditafsirkan dengan bantuan QS. al-Nahl: 25. Kedua, perhatiannya pada aspek semantik dengan bantuan bahasa dan tradisi orang Arab. Misalnya, penamaan Baìt al-'atī $q^{100}$ menurut Mujāhid dikarenakan tidak akan seorang pun yang berniat jahat untuk mendatangi tempat tersebut kecuali ia akan celaka. Demikian pula, Mujāhid menafsirkan kata "afalam yay'asi"101 dengan arti "afalam yatabbayyanu” (tidakkah telah jelas atau terang). ${ }^{102}$

Ketiga, menggunakan logika. Misalnya penafsiran Mujāhid pada QS. al-Qiyāmah: 22-23. Menurutnya, maksud ayat ini yaitu kesempatan bagi seorang mukmin untuk melihat pahala dari Allah, bukan dijadikan legitimasi tentang kesempatan melihat Tuhan dengan mata kepala telanjang bagi seorang mukmin untuk melihat Tuhan kelak pada hari kiamat sebagaimana paham kelompok sunni. ${ }^{103}$ Demikian pula, Mujahid menafsirkan QS. alBaqarah: 65 secara rasional, bahwa yang dirubah menjadi kera bukan pada struktur fisiknya, akan tetapi hanya sebatas perubahan hatinya. Dalam konteks ini, lanjut Mujahid, ayat tersebut dimaksudkan oleh Allah sebagai bentuk perumpaan an-sich, sebagaimana kasus yang terjadi dalam QS. alJumu'ah: 5. ${ }^{104}$ Dengan cara yang demikian, hemat penulis, Mujāhid telah

\footnotetext{
${ }^{100}$ QS. al-Hāj: 29

${ }^{101}$ QS. al-Ra'du: 31

${ }^{102}$ al-T abarì, Jāmi' al-Bayān,.....Juz XVI, 454.

${ }^{103}$ Ibnu Kathï, Tafsìr al-Qur'ān,.....Juz VI, 450. Menurut Husain al-Dhahabī, logika berpikir Mujāhid terkait dengan penafsiran ayat tersebut didasarkan pada ideologi Mu'tazilah. Lihat; Muhammad Husain al-Dhahabī, al-Tafsirir wa al-Mufassirūn,..... 106.

${ }^{104}$ al-Ṭabarī, Jāmi' al-Bayān,.....Juz II, 65. Bandingkan dengan; Ibnu Kathīr, Tafsìir alQur'ān,.....Juz I, 279. Menurut Shaikh Rashid Riḍā, perubahan tersebut hanya dari sisi sifatsifat atau perilakunya saja, misalnya cara melompatnya persis dengan cara kerja melompatnya kera dan cara pemuasan nafsu seksualnya sama dengan cara pelampiasannya seekor babi. Lihat; Muhammad Rashid Rị̣ā, Tafsìr al-Qur'ān al-Hakìm, Juz VI (Mesir: alHai'ah al-Misriyyah, 1990), 371.
} 
Potret epistemologi tafsir era formatif

(peta kajian tafsir klasik perspektif filsafat ilmu)

melepaskan belenggu penafsiran dari yang irrasional menuju penafsiran yang rasional.

\section{Epilog}

Tafsir era formatif merupakan sebuah model atau cara berpikir yang kurang memaksimalkan atau memberikan porsi lebih pada penggunaan rasio dalam menafsirkan al-Qur'an dan juga belum mengemukakannya budaya kritisisme. Artinya, dalam konteks peran dan posisi akal, tafsir era formatif menjadikan peran akal hanya sebagai instrumen yang bersifat partisipatif, sedangkan peran periwayatan diberikan porsi sebagai alat jastifikatif. Kondisi yang demikian tentu sangat berbeda dengan model dan cara kerja tafsir pada era berikutnya, yaitu era pertengahan. Pada era tersebut, posisi akal sebagai instrumen yang bersifat jastifikatif, sedangkan posisi periwayatan diberikan peran sebagai alat partisipatif. Dengan demikian, era tafsir formatif merupakan model berpikir nalar-quasi kritis.

Rosulullah yang diberikan legislasi untuk menginterpretasikan ayatayat yang terdapat dalam al-Qur'an, betapa-pun beliau sangat aktif terlibat dalam penafsiran al-Qur'an, namun tidak semua ayat al-Qur'an ditafsirkan beliau. Keterlibatan tersebut hanya dalam rangka menjelaskan ayat yang dianggap sulit saja oleh sebagian sahabat. Jarangnya Nabi saw. melakukan penafsiran terhadap ayat-ayat al-Qur'an lebih dikarenakan sasaran wahyu pada waktu itu adalah orang-orang Arab asli yang menguasai bahasa Arab dan memiliki cita rasa bahasa (Dhauq al-Lughah al-Salim) yang cukup baik, sehingga mereka dapat memahami al-Qur'n dengan baik dan mengetahui aspek-aspek balaghah yang ada di dalamnya, mengingat al-Qur'an diturunkan dengan menggunakan bahasa mereka.

Adapun mengenai tradisi dan sistem penafsiran di era sahabat dan tabi'in masih bersifat oral dengan menggunakan metode periwayatan (bi alriwāyah). Hasil penafsiran dari Nabi saw. itulah yang ditransmisikan kepada generasi berikutnya. Trend penafsiran dengan al-riwāyah ini ditengarai karena adanya sikap kehati-hatian mereka yang dimungkinkan akan tergelincir pada kesalahan. Namun, ketika para sahabat dan tabi'in tidak menemukan penjelasan dari Nabi saw., maka dengan mudah mereka merujuk pada penggunaan bahasa dan syair-syair Arab, sebagaimana yang dilakukan Sayyidina Umar bin al-Khattab. Selain itu, penafsiran di era sahabat di samping al-Qur'an, hadis, bahasa dan syair-syair Arab adalah variasi bacaan (qirä’ah) al-Qur'an. 
Potret epistemologi tafsir era formatif

(peta kajian tafsir klasik perspektif filsafat ilmu)

\section{Daftar Pustaka}

al-Afriqīi, Ibnu Manzūr. Lisān al- 'Arab, Jilid V. Beirut: Dar al-Sadr, 1992.

Amin, Ahmad. Fajr al-Islām , Kairo: Maktabah al-Nahụah al-Mișriyah, 1975.

al-Alūsì, Shihāb al-Dīn Mahmūd bin 'Abdullāh al-Husainì. Rūh al-Ma'ānì fí Tafsìr al-Qur'ān al-'Azìim wa al-Sab'u al-Mathānì, Juz XVI, Bierut: Dār al-Kutb, 1415.

al-'Asqalāni, Ibnu Hajar. Fath al-Bāri, Juz I, Beirut: Dār al-Fikr, t.th.

al-Asyūtị, Abū Muhammad. Tafsìr Mujāhid, Beirut: Dār al-Kutub alIlmiyyah, 2005.

'Āṣi, Muhammad Salim Abū. 'Ulūm al-Qur'ān 'inda al-Shātibì, Juz I , Kairo: Dār al-Basair, 1426.

al-Bantani, al-Nawawi. Marah Labīd li Kashfi Ma'nā al-Qur'an al-Majīi, Juz I , Beirut: Dār al-Kutub, 1418.

al-Bigā, Mustafā Dib. al-Wādih fì 'Ulūm al-Qur'ān, Damaskud: Dār al'Ulūm al-Insaniyah, 1418.

al-Būṭì, Muhammad Saìd Ramaḍān. Min Rawā'iu al-Qur'ān; Ta'ammalāt 'Ilmiyyah wa Adabiyyah fí Kitābillāh, Juz I , Beirut: Mu'asasah alRisālah, 1420.

al-Bukhāri, Imām. Sahīh al-Bukhärī, Juz VI, bab Kitab Tafsir. t.th.

al-Darwisy, Muhyiddin. I'rāb al-Qur'ān wa Bayānuhū, Juz V, Syiria; Dār alIrsyad, t.th.

al-Dhahabi, Muhammad Husain. "'Ilmu al-Tafsir" dalam Buhüth fì 'Ulüm al-Tafsir wa al-Fiqh wa al-Da'wah, Kairo: Dār al-Hadith, 1426.

-------------, Ibnu 'Arabī wa Tafsìr al-Qur'ān; Haqīq al-Tafsìr al-Mansūb Ilaihi, Kairo: Dār al-Hadith, 1426.

----------, al-Tafsìr wa al-Mufassirūn, Vol. I , Beirut: Dār al-Fikr, 1396.

al-Fairuzabadì, Abū Țāhir Ibn Ya'qūb. Tanwìr al-Miqbās min Tafsìr Ibn 'Abbās, Beirūt: Dār al-Fikr, t.th..

el-Fadhl, Khaled M. Abou. Atas Nama Tuhan; Dari Fiqih Otoriter ke Fiqih Otoritatif, terj. Cecep Lukman Yasin. Jakarta: Serambi, 2004.

Fathurrosyid. Semiotika Kisah al-Qur'an; Membedah Perjalanan Religi Raja Sulaiman dan Ratu Balqis dalam al-Qur'an. Surabaya: Pustaka Radja, 2013.

Goldziher, Ignaz. Madzhab Tafsir, terj. M. Alaika Salamullah ,Yogyakarta: eLSAQ Press, 2006.

Ḥakim, Muhammad Bāqir. 'Uh̄m al-Qur'ān, ter. Nashirul Haq dkk, Jakarta: al-Huda, 2006.

al-Hamad, Gānim Qaddūrì. Muhādarāt fì 'Ulūm al-Qur'ān , Ammān: Dār 'Ammār, 1423. 
Potret epistemologi tafsir era formatif

(peta kajian tafsir klasik perspektif filsafat ilmu)

'Itr, Nur al-Dīn. 'Ulūm al-Qur'ān, Juz I , Damaskus: Matba'ah al-Sabah, 1414.

Ja'far, 'Abd al-Ghāfūr Mạ̣mūd Muṣtafā. al-Tafsìr wa al-Mufassinūn fí Thaubihi al-Jadid, Kairo: Dār al-Salām, 2007.

Jawād, Abdul Jawād Khalaf Muhammad Abdul. Madkhal ilā al-Tafsìir wa 'Ulūm al-Qur'ān, Juz I , Kairo: Dār al-Bayān al-Arabī, t.th.

al-Judai', Abdullah bin Yūsuf. al-Muqaddimāt al-Asāsiyat fí 'Ulūm al-Tafsìr , Beirut: Muasasah al-Rayyān, 1422.

al-Jurjānì. Kitāb al-Ta’rifăt. Beirut: Dār al-Kutub al-'Ilmiyyah, 1998.

Kathìr, Ibnu. Tafsìr al-Qur'ān al- 'Azìm, Juz II , Beirūt: Dār Ihya', t.th.

Khaldūn, Ibnu. Muqaddimah Ibnu Khaldūn, Bairūt: Dār al-Fikr: t.th.

Khalafullah, Muhammad Ahmad. al-Fann al-Qașași fì al-Qur'ān al-Karīm, Kairo: Maktabah al-Nahḍah al-Mișriyyah, 1951.

al-Khudlairì, Muhammad 'Abdullāh ibn 'Ali. Tafsìr al-Täbi'īn, Vol.1 , Riyād: Dār al-Watan wa al-Nashr, 1999.

Ma'luf, Louis. Al-Munjid fĩ al-Lughah wa al-A'lam, Beirut: Maktabah alShariqah, 1996.

Mustaqim, Abdullah. Epistemologi Tafsri Kontemporer. Yogyakarta: LKiS, 2010.

Na'na'ah, Ramzìi. al-Isrā'iliyyāt wa Atharuhā fî Kutub al-Tafsìr, Damaskus: Dār al-Qalam, 1390.

Nasrulloh. Ayat Ayat Al-Qur'an Yang Tidak Dapat Difahami Tanpa Historisitasnya (Sabab Al-Nuzul), Tesis IAIN Sunan Ampel Surabya, 2009.

al-Qatțān, Mannā'. Mabāhith fì 'Uh̄̄m al-Qur'ān, t.tp: Manshurāt al-'Așr alHadith, 1973.

al-Qādir, Muhammad 'Ali 'Abd. Faị̣ al-Raḥmān fí 'Uh̄̄m al-Qur'ān, Kairo: Dār al-Ṭibā'àt al-Muhammadiyah, 1986.

al-Qurțūbì. al-Jāmi' li Ahk̄ām al-Qur'ān, Juz I, Kairo: Dār al-Kutub al'Arabi, 1387.

al-Qinnaujī. Fath al-Bayān fì Maqāsid al-Qur'ān, Juz I ,Beirut: al-Maktabah al-'Asriyyah, 1412.

Rusyd, Ibnu. Bidayāt al-Mujtahid, Juz II, Beirūt: Dār Ma’rifah, t.th..

Riḍā, Muhammad Rashīd. Tafsìir al-Qur'ān al-Hakīm, Juz VI ,Mesir: alHai'ah al-Misriyyah, 1990.

al-Rāzì. Mafătīh al-Gaīb, Juz XI , Beirut: Dār al-Kutb, 1421.

al-Sabāgh, Muhammad bin Lutfí. Lamhät fì 'Ulūm al-Qur'ān wa Ittijāhāt alTafsir, Beirüt: al-Maktab al-Islāmi, 1410.

al-Șābūnī, Muhammad Ali. al-Tibyān fì 'Ulūm al-Qur'ān, Beirūt: Dār alKutub al-Islāmiyyah, 1424. 
Potret epistemologi tafsir era formatif

(peta kajian tafsir klasik perspektif filsafat ilmu)

Salih, Abdul Qadir Muhammad. al-Tafsìr wa al-Mufassiruñ fī al-'Asri alHadith, Beirūt: Dār al-Ma'rifah: 1424.

Sālih, Hamād bin. Muhādarat fí 'Ulūm al-Qur'ān, Juz I, Ammān: Dār Ammār, 1423.

Shuhbah, Muhammad Abū. al-Madkhal li Dirāsat al-Qur'ān al-Karīm, Juz I, Kairo: Maktabah al-Sunnah, 1423:

al-Suyūțì, Jalāl al-Dīn Abū al-Faḍl 'abd al-Raḥmān. al-Dur al-Manthūr, Juz VI, Beirūt: Dār al-Ma'rifah, t.th..

---------, Jalāl al-Dīn Abu al-Fạ̣l 'abd al-Raḥmān. al-Itqān fì 'Ulūm alQur'ān,Vol. 2, t.tp: Dār al-fikr, t.th.

---------, Jalāl al-Dīn Abu al-Faḍl 'abd al-Rahmmān. Tadrīb al-Rāwi fị Sharh Taqrīb al-Nawāwi, Vol.2, t.tp: Dār al-Fikr, t.th.

al-Ṭabarì. Jāmi' al-Bayān 'an Ta'wìli Āyi al-Qur'ān, Juz I, Kairo: Dār alMa'arif, tth.

al-Tayyār, Musā'id bin Sulaimān. Fuṣūl fì Usūl al-Tafsìr, Riyād: Dār alNashr al-Dauli, 1413.

Wajdi, Muhammad Farīd. Dāirah Ma'arif al-Qarn al-'Isyrīn, Jilid VII. Beirūt: Dār al-Fikr, t.th.

Al-Zamakhsharì. al-Kashshāf 'an Haqà'iq Gawāmid al-Tanzīl wa 'Uyūn alAqāwìl fì Wujūh al-Ta'wìl, Juz I, Beirut: Dār al-Kitab, 1407.

al-Zarkashi, Muhammad Ibn 'Abdullah. Al-Burhān fí 'Ulūm al-Qur'ān, Juz I Beirūt: Dār al-Ma' arifah,1972.

al-Zarqānì, Manāhil al-'Irfān, Vol. 2 (Beirūt: Dār al-Kutb al-'Ilmiyyah, t.th.

Zarzūr, 'Adnan Muhammad. 'Ulūm al-Qur'an̄: Madkhal ilā Tafsìr al-Qur'ān wa Bayānu I’Jāzihī, Beirūt: al-Maktab al-Islamī, 1401. 